\title{
Magyarországra behurcolt trópusi arbovírusfertőzések 2016 és 2020 között
}

\author{
Nagy Orsolya dr. ${ }^{1,2}$ - Nagy Anna ${ }^{1}$ - Tóth Szilvia dr. ${ }^{3}$ \\ Koroknai Anita dr. ${ }^{1}$. Takács Mária dr. ${ }^{1,2}$ \\ ${ }^{1}$ Nemzeti Népegészségügyi Központ, Virológiai Laboratóriumi Osztály, Budapest \\ ${ }^{2}$ Semmelweis Egyetem, Általános Orvostudományi Kar, Orvosi Mikrobiológiai Intézet, Budapest \\ ${ }^{3}$ Dél-pesti Centrumkórház - Országos Hematológiai és Infektológiai Intézet, Infektológiai Osztály, Budapest
}

Bevezetés: A Dengue-, Zika- és Chikungunya-vírus-fertőzések a trópusokról importált leggyakoribb arbovírusfertőzések. Földrajzi elterjedésük átfedő, közös vektoraik és hasonló tüneteik miatt szerológiai és molekuláris módszerek együttes alkalmazásán alapuló mikrobiológiai vizsgálatokkal különíthetők el megbízhatóan.

Célkitüzés: Munkánk célja a 2016 és 2020 között endémiás területen járt, tünetes és tünetmentes utazók vizsgálata volt, minden esetben mindhárom vírusfertőzés irányában. A diagnosztikus tesztek során az alvadásgátolt teljes vér és vizelet bevonásával vizsgáltuk a vírus-RNS kimutathatóságának esélyét a különböző mintatípusokból.

Módszer: Savópárminták szerológiai analízise során a Dengue-, Zika- és Chikungunya-vírus-specifikus ellenanyagválasz alakulását vizsgáltuk ELISA-módszerrel. Reaktív eredmények esetében a szerológiai keresztreakciók kizárására immunfluoreszcens és ELISA-technikán alapuló további vizsgálatokat végeztünk a hazai és az utazás során érintett területeken előforduló flavi- és alphavirusok irányában. Vérsavó-, alvadásgátolt teljes vér és vizeletmintákból reverztranszkripciót követő valós idejű polimeráz-láncreakcióval vírus-RNS-kimutatást végeztünk.

Eredmények: Az 1037 vizsgált utazó közül 133 esetben kaptunk reaktív szerológiai és/vagy molekuláris eredményt. Az alvadásgátolt teljes vér mintából sikerült a legnagyobb arányban vírusnukleinsavat kimutatni mind a Dengue- és Zika-, mind a Chikungunya-vírus esetében.

Megbeszélés: Endémiás területről hazatért utazók vizsgálatát a tünetek hasonlósága miatt mindhárom vírusfertőzés irányában együttesen indokolt elvégezni. A flavi- és alphavirusokra jellemző nagyfokú szerológiai keresztreaktivitás miatt a nukleinsav-kimutatás javíthatja a mikrobiológiai diagnosztika pontosságát.

Következtetés: A három vírus mikrobiológiai diagnosztikáját segíti a korai mintavétel és a molekuláris vizsgálatok kiterjesztése további mintatípusokra: alvadásgátolt teljes vér és vizelet. A behurcolt vírusfertőzések azonosítása fokozott jelentőségú, mert az Európában is jelen lévő vektorszúnyogfajok felvetik az autochton átvitel lehetôségét.

Orv Hetil. 2021; 162(50): 2000-2009.

Kulcsszavak: Dengue-vírus-fertőzés, Zika-vírus-fertőzés, Chikungunya-vírus-fertőzés, laboratóriumi differenciáldiagnosztika

\section{Imported tropical arbovirus infections in Hungary between 2016 and 2020}

Introduction: Dengue-, Zika- and Chikungunya infections are among the most frequently imported tropical arbovirus infections. Due to their shared endemic regions, vectors and similar clinical symptoms, differential diagnosis is based on serological and molecular analysis.

Objective: The aim of our study was to identify the imported arbovirus infections of travellers between 2016 and 2020. Furthermore, to improve the diagnostic sensitivity, anticoagulated whole blood and urine samples were involved in molecular diagnosis.

Method: Virus-specific antibody kinetics was tested in paired sera of patients by ELISA method. In case of reactive results, further serological analysis was performed using immunofluorescence assays and/or ELISA tests to exclude serological cross-reactions caused by other members of the flavi- and alphaviruses. Detection of viral RNA was attempted from serum, anticoagulated whole blood and urine specimens using reverse transcription and real-time polymerase chain reaction.

Results: Out of the tested 1037 travellers, reactive serological and/or molecular results were obtained in 133 cases. Anticoagulated whole blood proved to be the most suitable specimen for viral RNA detection of the three viruses. 
Discussion: Parallel testing of Dengue-, Zika- and Chikungunya infections is recommended, as symptom-based differential diagnosis is challenging. Due to the characteristic serological cross-reactivity of flavi- and alphaviruses, microbiological diagnosis relies on both serological and molecular tests.

Conclusion: Involving anticoagulated whole blood and urine samples into molecular analysis and early sample collection improve the sensitivity of microbiological diagnostics. Identification of imported tropical arbovirus infections is of high importance as the presence of vector mosquitos in Europe raises the possibility of autochthon transmission.

Keywords: Dengue-virus infection, Zika-virus infection, Chikungunya-virus infection, differential diagnosis

Nagy O, Nagy A, Tóth Sz, Koroknai A, Takács M. [Imported tropical arbovirus infections in Hungary between 2016 and 2020]. Orv Hetil. 2021; 162(50): 2000-2009.

(Beérkezett: 2021. március 12.; elfogadva: 2021. április 7.)

\section{Rövidítések}

$\mathrm{CHIKV}=$ Chikungunya-vírus; DENV = Dengue-vírus; EDTA $=($ ethylenediaminetetraacetic acid $)$ etilén-diamin-tetraecetsav; ELISA $=$ (enzyme-linked immunosorbent assay) enzimhez kapcsolt immunszorbensteszt; $\mathrm{Ig}=$ immunglobulin; JEV = japán encephalitisvírus; KEV = kullancsencephalitis-vírus; PCR $=($ polymerase chain reaction $)$ polimeráz-láncreakció; RNS = ribonukleinsav; SARS-CoV-2 = (severe acute respiratory syndrome coronavirus 2) súlyos akut légúti tünetegyüttest okozó koronavírus-2; USUV = Usutu-vírus; WNV = (West Nile virus $)$ nyugat-nílusi vírus; YFV = (yellow fever virus) sárgalázvírus; ZIKV = Zika-vírus

A trópusi, szubtrópusi területeken előforduló arbovírusfertőzések közül napjainkban a turizmussal összefüggő legnagyobb közegészségügyi veszélyt a Zika-vírus (ZIKV), a Dengue-vírus (DENV) és a Chikungunyavírus (CHIKV) okozta fertőzések jelentik [1]. Ezek a zoonoticus vírusok elsődlegesen sylvaticus körülmények között ízeltlábú vektorok segítségével majmok közt cirkulálnak, de emberre is átterjedhetnek, majd urbánus körülmények között szúnyogcsípéssel emberról emberre terjedve járványok kialakulását okozhatják $[2,3]$ (1. ábra). Mindamellett, hogy a három vírus elterjedési területe jelentősen átfedi egymást (2. ábra), és terjesztésükért közös ízeltlábú vektorok, az Aedes szúnyogok felelősek, az általuk okozott tünetek hasonlósága is nehezíti a klinikai diagnózist [4]. Ezen okok miatt mikrobiológiai vizsgálatok nélkül az elkülönítésük az esetek

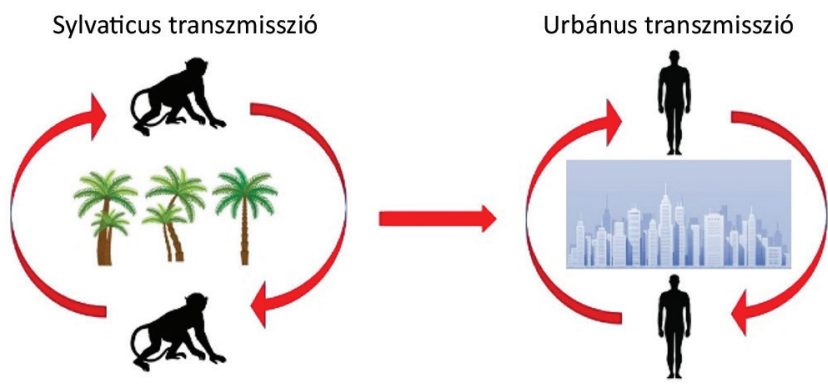

1. ábra

| A Dengue-, Zika- és Chikungunya-vírusok transzmissziós ciklusa többségében nem lehetséges, így az endémiás területről érkező utazók laboratóriumi vizsgálatát mindhárom vírusfertőzés irányában együttesen indokolt elvégezni [5]. A mikrobiológiai vizsgálatok során kihívást jelent a rövid ideig tartó viraemián kívül a flavi- és alphavirusok diagnosztikája kapcsán tapasztalható nagyfokú keresztreaktivitás $[6,7]$, amely miatt a trópusi-szubtrópusi területeken előforduló más flavivirusok (például a sárgaláz-, a japán encephalitis-, a nyugat-nílusi-vírus), valamint a hazai endémiás flavivirusok (a kullancsencephalitis-, a nyugat-nílusi-, az Usutu-vírus) [8,9] okozta esetleges fertőzésből vagy flavivirusok elleni korábbi immunizációból (KEV, YFV, JEV) adódó ellenanyagok vizsgálatát is indokolt elvégezni reaktív szerológiai eredmények esetén. Az alphavirusok közötti szerológiai keresztreakció is jelentős, emiatt ki kell zárni más, a térségben előforduló alphavirusok, mint például a Dél-Amerikában endémiás Mayaro- vagy az Európában is előforduló Sindbis-vírus okozta fertőzéseket is [10]. A hazai és az importált flaviés alphavirusok mikrobiológiai diagnosztikai vizsgálatát a Nemzeti Népegészségügyi Központ Virális Zoonózisok Nemzeti Referencia Laboratóriuma végzi, ahol 2016 és 2020 között összesen 1037 személy vizsgálata készültt el szerológiai és molekuláris módszerekkel.

A ZIKV a Flaviviridae család Flavivirus nemzetségéhez tartozó ízeltlábú vektorok terjesztette arbovírus, mely az 1947-ben Afrikában történt izolálása óta kezdetben csak sporadikus fertőzéseket okozott Afrikában és Délkelet-Ázsiában. Az első jelentősebb ZIKV-járvány 2007-ben zajlott Mikronéziában [11], majd a 2013-ban Francia Polinéziában zajló járvány során kiugróan megnőtt a neurológiai komplikációval, köztük a GuillainBarré-szindrómával járó esetek száma [12]. A 2015-ben Brazíliából kiinduló, nagyméretú járvány kapcsán derült fény a várandósok fertőződése során kialakuló microcephaliát és más idegrendszeri fejlődési rendellenességet okozó ZIKV congenitalis szindrómára [13], amely miatt az Egészségügyi Világszervezet (WHO) 2016. február és november között nemzetközi egészségügyi veszélyhelyzetet hirdetett [14]. A számos, Európába importált fertőzés mellett 2019-ben autochton (nem behurcolt, 


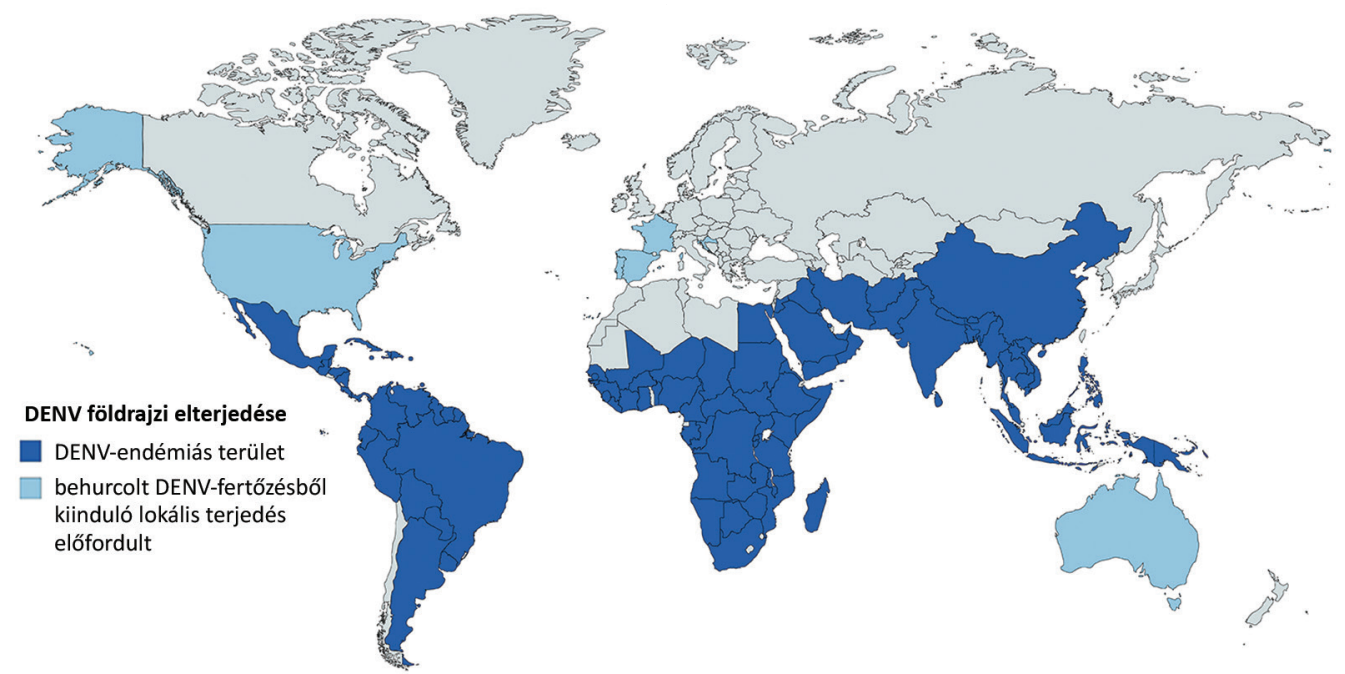

2/a ábra | A Dengue-vírus-fertózések földrajzi elterjedése

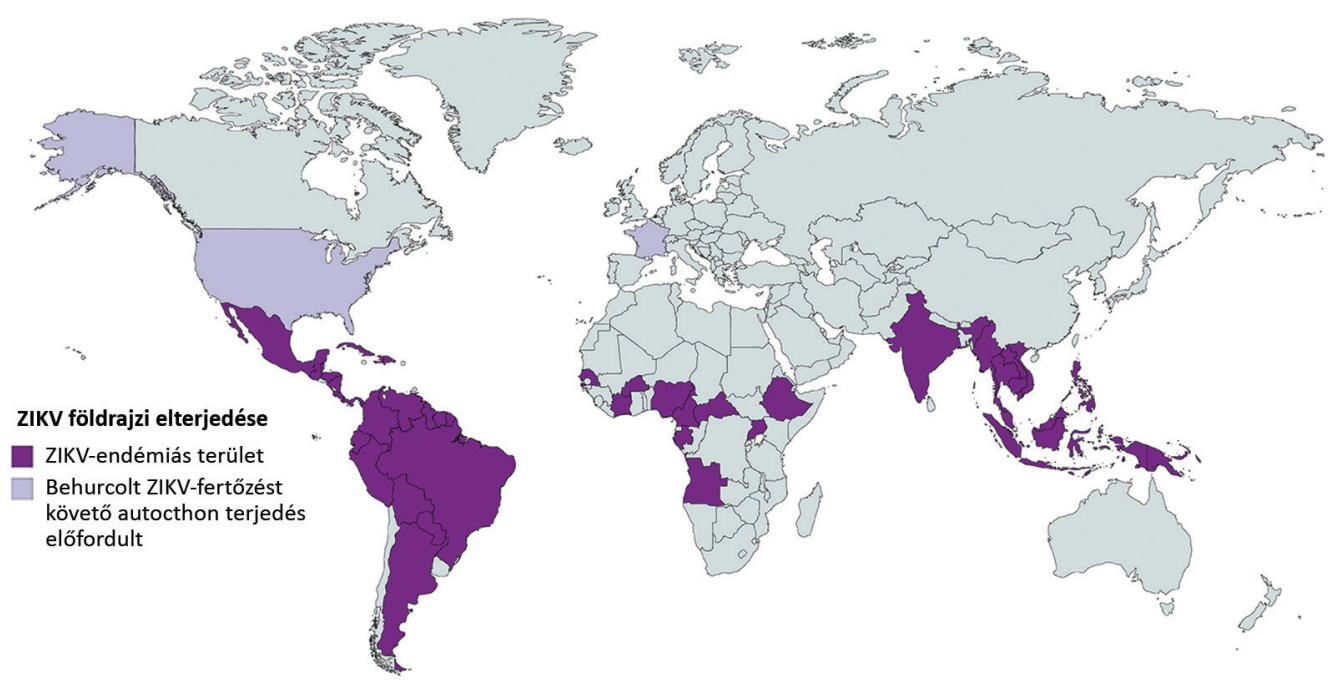

2/b ábra | A Zika-vírus-fertózések földrajzi elterjedése

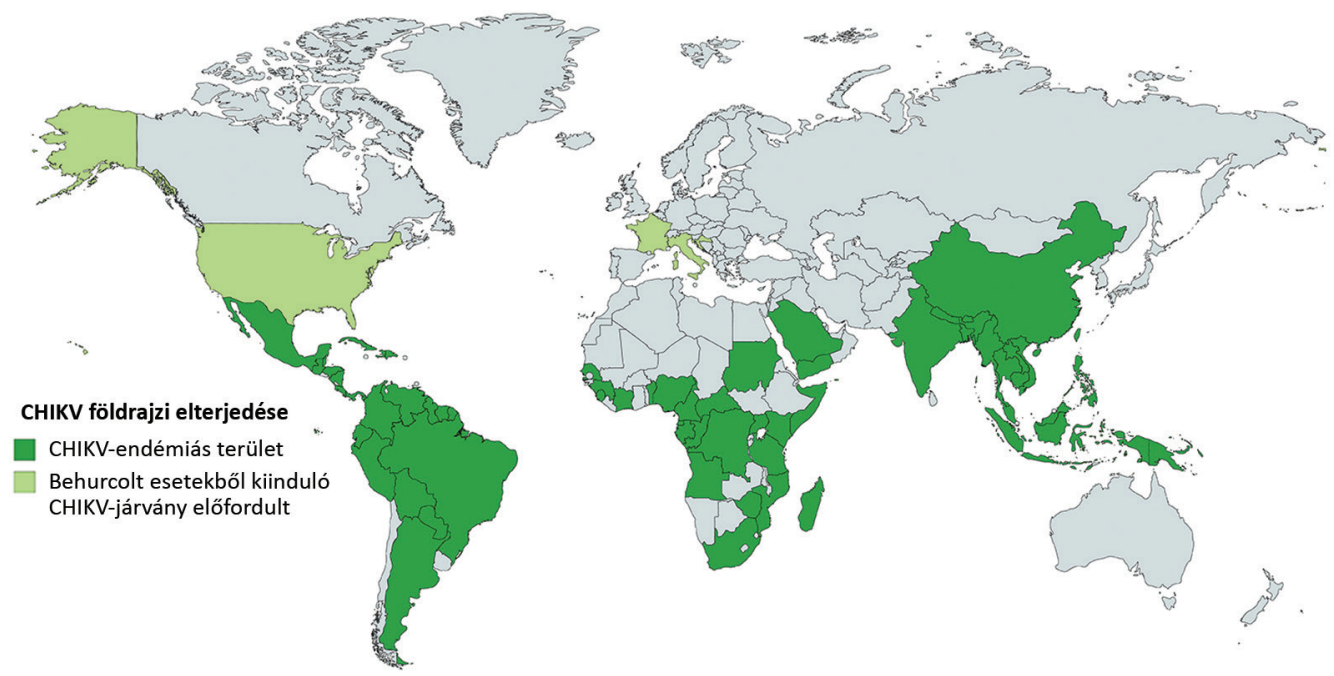

2/c ábra | A Chikungunya-vírus-fertózések földrajzi elterjedése 
helyben kapott) ZIKV-transzmissziót jelentettek a franciaországi Var régióból [15].

A fertőzés átvitele elsődlegesen az Aedes szúnyogok csípésével történik (elsődleges vektora az Aedes aegypti, de más Aedes fajok, köztük a számos európai országban elterjedt Aedes albopictus is szerepet játszhat az átvitelében). A vírus transzfúzióval, transzplantáció során, anyáról magzatra és szexuális úton is átadható [16].

A ZIKV-fertőzések 75-80\%-a tünetmentesen zajlik, és a tünetes megbetegedések nagy része is enyhe formában jelentkezik: 3-12 napos lappangási idő után általános bevezető tünetek, láz vagy hőemelkedés, majd maculopapularis kiütések, izom- és ízületi fájdalom, esetleg serosus kötőhártya-gyulladás képében. Ritkán neurológiai komplikációk alakulhatnak ki: meningitis, meningoencephalitis, Guillain-Barré-szindróma. Várandós nők fertőződése spontán vetéléshez, koraszüléshez, halva születéshez, illetve ZIKV congenitalis szindróma (microcephalia, corticalis/subcorticalis calcificatio, ventriculomegalia, cerebellaris hypoplasia, sensoneuronalis halláskárosodás, nervus opticus hypoplasia, macularis/ chorioretinalis atrophia) kialakulásához vezethet [1719]. Ezt elkerülendő, várandósok és gyermeket tervező párok számára az endémiás területre történő utazás nem javasolt a gyermekvállalás előtti 3 hónapban és a várandósság ideje alatt. Tekintettel a szexuális úton történő átvitel lehetőségére, az apa utazása sem javasolt. ZIKVfertőzés irányában a várandósgondozás keretében szưrővizsgálat végzendő azon várandós nők részére, akik a várandósság alatt vagy az azt megelőző két hónapban ZIKV-fertózésnek voltak kitéve [20]. Amennyiben tünetek nem jelentkeznek, az expozíciót követó 7-10. napon, majd ismételten a 4 . héten vérsavó, vizelet és EDTA-val alvadásgátolt vér küldendő a Nemzeti Népegészségügyi Központ Virális Zoonózisok Nemzeti Referencia Laboratóriumába. Tünetek jelentkezése esetén mielóbbi mintabeküldés javasolt. ZIKV-fertőzésre utaló szerológiai és/vagy molekuláris vizsgálati eredmények esetén nőgyógyász szakorvos javaslatára a magzatvíz molekuláris vizsgálata elvégezhető.

A ZIKV-fertőzés megelőzése a szúnyogcsípések elleni védekezésen alapul, specifikus terápia nem áll rendelkezésre, csak szupportív kezelés [17].

A DENV a ZIKV-hoz hasonlóan a Flaviviridae család Flavivirus nemzetségéhez tartozó arbovírus, mely az 1943. évi első izolálását követően a világ trópusi és szubtrópusi területein vált endémiássá. A Föld lakosságának mintegy fele ki van téve a DENV-fertőzésnek, és az új fertôzések becsült száma évente 390 millió fó [21]. Európában is évről évre előfordulnak behurcolt fertőzésekből kiinduló helyi megbetegedések és kisebb járványok is. A legjelentősebb európai DENV-járvány 2012 2013-ban zajlott Madeirán, melynek során több mint 2000 fertőzöttet diagnosztizáltak [22]. Négy szerotípusa különíthető el: DENV-1, DENV-2, DENV-3 és DENV-4; az ezek ellen termelt antitestek nagyfokú keresztreakciót mutatnak a szerológiai vizsgálatok során, de az egyik szerotípussal történt fertőzés átvészelése nem ad védettséget a többi szerotípussal szemben, sốt a flavivirusokra jellemző ellenanyagfüggő fertőződésfokozódás miatt a második fertózés általában súlyosabb tünetekkel zajlik [23]. Az Aedes szúnyogok csípésével vagy ritkábban transzfúzióval vagy transzplantációval átvitt fertőzés után kialakulhat tünetmentes lefolyás, enyhébb tünetekkel (kiütés, láz, izom-ízületi fájdalom) járó Dengue-láz vagy súlyos, akár halálos kimenetelú Dengue vérzéses láz és Dengue-sokk szindróma, melynek során 3-7 nappal a Dengue-lázra jellemző bevezető tünetek után erős hasi fájdalom, nyálkahártyavérzés, majd sokszervi elégtelenség alakulhat ki. A tünetes DENV-fertôzések kezdeti szakaszában kifejezett neutropenia, majd thrombocytopenia és májenzim-emelkedés figyelhető meg [21, 24, 25]. A súlyos lefolyású megbetegedésben szenvedő pácienseket megfelelően felkészült kórházi osztályon adekvát szupportív terápiában szükséges részesíteni. 2019 óta az Európai Unióban is engedélyezett a Dengvaxia nevú, élő-attenuált vírust tartalmazó oltóanyag, mely a korábban igazoltan DENV-fertőzésen átesett, 9-45 év közötti személyek második DENV-fertőzésének megelőzésére adható. Szeronegatív személyeknek egy későbbi fertőzés során esetlegesen kialakuló ellenanyagfüggő fertőződésfokozódás veszélye miatt nem adható [26]. A fertőzés megelőzése ezenkívül a szúnyogcsípések elleni védekezésen alapul.

A CHIKV a Togaviridae család Alphavirus nemzetségéhez tartozik. A ZIKV-hoz és a DENV-hoz hasonlóan elsődlegesen az Aedes szúnyogok közvetítésével terjed. Kezdetben csak Afrika és Ázsia trópusi-szubtrópusi területein fordult elö, majd 2013-ban megjelent és elterjedt az amerikai kontinensen is [27, 28]. Bár Európában nem számít endémiásnak, a mediterrán térségben is leírtak behurcolt fertőzésből kiinduló helyi terjedést Franciaországban és Olaszországban is [29-33]. A fertőzések mintegy 75\%-ában alakul ki tünetes megbetegedés: 3-7 nap lappangási idő után magas láz, kötőhártya-belövelltség, kiütések és kifejezett ízületi fájdalom, duzzanat és következményes mozgáskorlátozottság jelentkezik [27]. Az ízületi panaszok a betegek egy részében krónikussá válhatnak és hónapokig fennmaradhatnak [34]. Ritkán közvetlen víruskárosító hatás miatt $1-2$ héttel a kezdeti tünetek után vagy autoimmun hátterü folyamatok miatt 6-8 héttel a fertózés után központi idegrendszeri panaszok alakulhatnak ki [35]. A flavivirusfertőzésekhez hasonlóan a CHIKV okozta panaszok ellen sem áll rendelkezésre specifikus antivirális terápia, csak szupportív kezelés. Védőoltás nem érhetô el. A megelőzés a szúnyogcsípések elleni védekezésen alapul.

A DENV-, ZIKV- és CHIKV-fertőzések mikrobiológiai vizsgálata molekuláris és szerológiai módszerek együttes alkalmazásával történik. Az endémiás területről érkező tünetes betegektől mikrobiológiai vizsgálatra a tünetek megjelenését követôen mielőbb, de legkésóbb a 1-7. napon vérsavó-, EDTA-val alvadásgátolt teljes vér, illetve vizeletminta küldendő a Nemzeti Népegészség- 
ügyi Központ Virális Zoonózisok Nemzeti Referencia Laboratóriumába. Korai mintavétel esetén a kórokozó nukleinsava nagy eséllyel kimutatható PCR-vizsgálattal a megfelelően tárolt és szállított klinikai mintából. (Amenynyiben lehetőség van a mintákat a mintavételt követő 1-3. napon a laboratóriumba juttatni, azokat $+4{ }^{\circ} \mathrm{C}$-on szükséges tárolni és szállítani. Hosszabb idő esetén ajánlott $-20{ }^{\circ} \mathrm{C}$-on fagyasztva tárolni és szállítani a mintákat.) Szakirodalmi adatok szerint ZIKV- és DENV-fertőzés esetében vizeletből és teljes vérből [36-39], CHIKV-fertőzés esetében teljes vérből hosszabb ideig is kimutatható maradhat a vírus RNS-e [40].

A PCR-teszt negatív eredménye azonban nem zárja ki az akut fertőzést. Negatív PCR esetében szerológiai módszerekkel savópár vizsgálata ajánlott; a második vérsavót a korai vérmintát követő 10-14. napon érdemes levenni.

Az akut fertőzések diagnosztikája a molekuláris és szerológiai eredmények együttes figyelembevételével történik, az Európai Tanács által elfogadott esetdefinícióknak megfelelően [41]:

A megerősített eset laboratóriumi kritériumai:

- a vírus izolálása klinikai mintából;

- a vírus RNS-ének kimutatása klinikai mintából;

- a vírus antigénjének kimutatása klinikai mintából;

- a vírussal szemben termelődött IgM-típusú ellenanyagok kimutatása vérmintából és megerôsítésük vírusneutralizációval;

- vírusspecifikus IgG-típusú ellenanyagok négyszeres titeremelkedése vagy seroconversio savópár vizsgálata során.

A valószínűsített laboratóriumi eset esetdefiníciója:

- a vírussal szemben termelődött IgM-típusú ellenanyagok kimutatása vérmintából.

\section{Módszer}

A Nemzeti Népegészségügyi Központ Virális Zoonózisok Referencia Laboratóriumában 2016 és 2020 között összesen 619, endémiás területen járt tünetes beteg diagnosztikai vizsgálata és 418 tünetmentes utazó szűrővizsgálata készült el DENV-, ZIKV- és CHIKV-fertőzés irányában. A tünetek hasonlósága és az elterjedési területek nagyfokú átfedése miatt a diagnosztikus vizsgálatokat mindhárom vírusfertőzés irányában elvégeztük a nemzetközi ajánlásoknak megfelelően [5]. Reaktív eredmények esetén az esetleges keresztreakciók kizárására további vizsgálatokat végeztünk más, a területen/hazánkban endémiás flavi-, alphavirusok irányában, figyelembe véve a betegek flavivirusok elleni oltási anamnézisét is (YFV, JEV, KEV). Szürővizsgálatot a ZIKV-fertőzés kizárására endémiás területen járt vagy egyéb módon a vírusfertőzésnek kitett várandós nők, illetve partnereik, továbbá endémiás területről hazatért, gyermeket tervező párok részére végeztünk. Surveillance keretében ezeket a mintákat tovább vizsgáltuk a DENV- és a CHIKV-fertőzés kizárása céljából is.
A vizsgált tünetes betegek közül 300 páciensnél jelentkezett legalább egy vírusspecifikus tünet: kiütés, ízületi fájdalom, kötőhártya-gyulladás, vérzéses tünetek vagy congenitalis ZIKV-szindrómára jellemző panaszok (3. ábra); 319 esetben nem specifikus panaszok jelentkeztek. 418 tünetmentes betegnél szerológiai módszerekkel szűrővizsgálatot végeztünk, és amennyiben a kapott eredmények akut fertőzés gyanúját vetették fel, a további szerológiai konfirmáló és molekuláris PCR-vizsgálatokat utólag, a fagyasztva tárolt mintákból végeztük el.

A vírus-RNS-kimutatás a specifikus tüneteket mutató betegek vérsavó-, alvadásgátolt teljes vér és vizeletmintáiból reverztranszkripciót követő valós idejű PCR-vizsgálattal történt. A szerológiai vizsgálatok során DENV-antigén-kimutatást végeztünk kereskedelmi forgalomban kapható ELISA-tesztek felhasználásával a szakirodalmi ajánlásoknak megfelelően a tünetek megjelenését követő 1-8. napon vett vérmintából [42], továbbá ZIKV-, CHIKV- és DENV-specifikus IgM-, illetve IgG-ellenanyag-kimutatást ELISA-módszerrel akut fázisban és a fertőzés convalescens szakaszában gyűjtött vérsavóból. IgA-ellenanyag-kimutatást szekunder flavivirusfertőzés gyanúja esetén végeztünk, szintén ELISA-módszerrel. Reaktív szerológiai eredmények esetén, amennyiben a molekuláris vizsgálatok és az antigénkimutatás eredményei nem igazolták egyértelmúen a fertőzést, a hazai endémiás flavivirusok (KEV, WNV, USUV), illetve a beteganamnézis alapján a korábban kapott, flavivirusok elleni oltások (KEV, YFV, JEV) okozta keresztreakciók kizárására IgM-, IgG- és IgA-ellenanyag-kimutatást végeztünk indirekt immunfluoreszcens módszerrel. Amennyiben felmerült, a trópusi területen előforduló más flavi- és alphavirusok okozta keresztreakciók kivizsgálására is szerológiai vizsgálatokat végeztünk ELISA- és/vagy immunfluoreszcens technikával. A valószínúsített DENV- és ZIKV-fertőzések pozitív szerológiai eredményeinek megerősítésére vírusneutralizációt végeztünk.

A kapott eredmények értékelése során figyelembe vettük a DENV-, ZIKV- és CHIKV-fertőzésekre jellemző sajátos ellenanyag-kinetikát és a különböző mintákból a vírus-RNS detektálhatóságát.

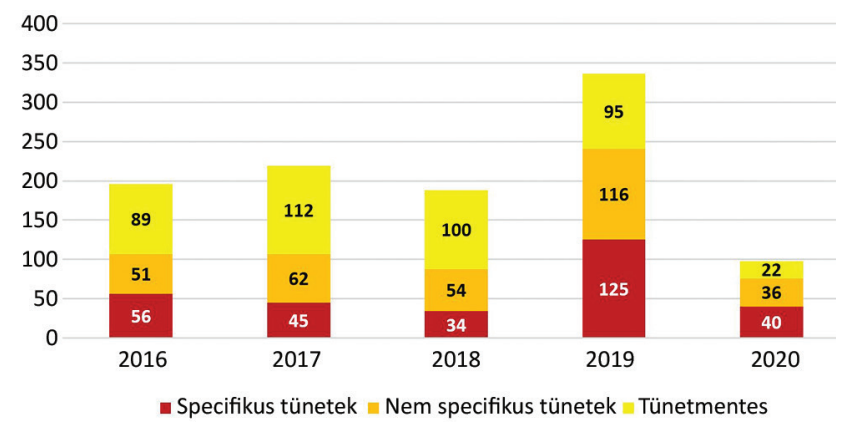

3. ábra A 2016 és 2020 között vizsgált betegek száma a tünetek megoszlása szerint 


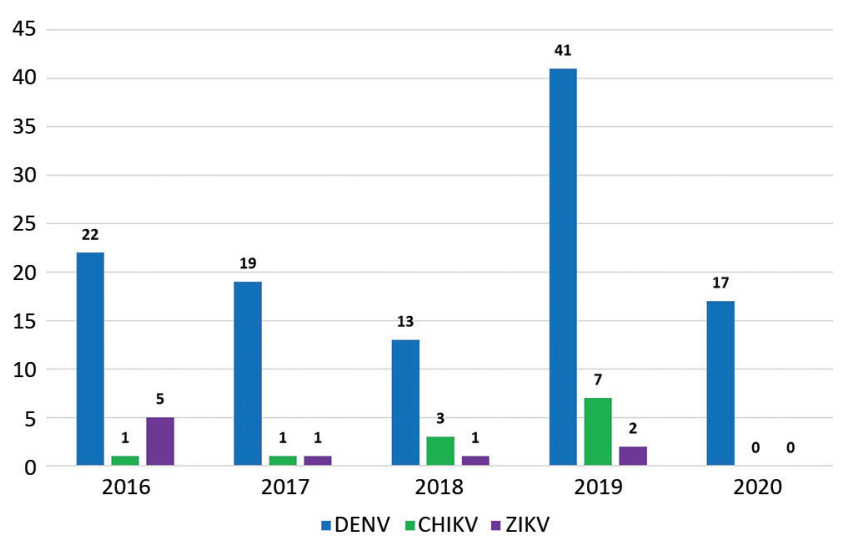

4. ábra

2016 és 2020 között diagnosztizált importált trópusi arbovírus-
fertőzések évenkénti megoszlása
CHIKV = Chikungunya-vírus; DENV = Dengue-vírus; ZIKV =
Zika-vírus

A rövid viraemiás szakasz miatt vérsavóból a vírusRNS-kimutatás a tünetek kezdetét követő néhány napban lehetséges, de a PCR-vizsgálatot alvadásgátolt teljes vérból a 7-10. napon is érdemes megkísérelni. A ZIKV és a DENV esetében a vizeletben is tovább detektálható maradhat a vírusnukleinsav a szakirodalmi adatok szerint [37-40].

Primer fertőzés esetén az IgM-ellenanyagok megjelenése a tüneteket követő 3-5 napon jellemző, és akár 3-6 hónapig is kimutathatók, míg az IgG-ellenanyagok átlagosan 7-10 nap elteltével válnak mérhetôvé, és élethoszszig perzisztálhatnak [43-45].

Komolyabb diagnosztikai kihívást jelent a második flavivirusfertőzések során tapasztalható alacsony vagy nem mérhető IgM-ellenanyag-szint és a korai magas IgG-titer, ami miatt négyszeres titeremelkedés savópár vizsgálata során már nem vagy csak ritkán tapasztalható [43].

\section{Eredmények}

Az öt év alatt 1037 tünetes és tünetmentes utazó vizsgálata során 133 esetben kaptunk reaktív szerológiai és/vagy molekuláris eredményt DENV-, ZIKV-, illetve CHIKV-fertőzés irányában:

- Három esetben aktuális, négy esetben korábban átvészelt ZIKV-fertőzést igazoltunk, míg egy betegnél aktuális és egy betegnél korábban átvészelt ZIKV-fertőzést valószínúsítettünk.

- Hét esetben igazoltunk aktuális CHIKV-fertőzést, míg két betegnél aktuális, három betegnél korábban átvészelt CHIKV-fertőzést véleményeztünk a kapott laboratóriumi eredmények alapján.

- Összesen 80 betegnél aktuális DENV-fertőzést igazoltunk, míg 21-nél aktuális és nyolcnál korábban átvészelt DENV-fertőzés volt valószínúsíthető az elvégzett mikrobiológiai vizsgálatok eredménye alapján.

A legtöbb ZIKV-fertózést 2016-ban [46], míg a legtöbb DENV- és CHIKV-fertőzést 2019-ben diagnoszti-

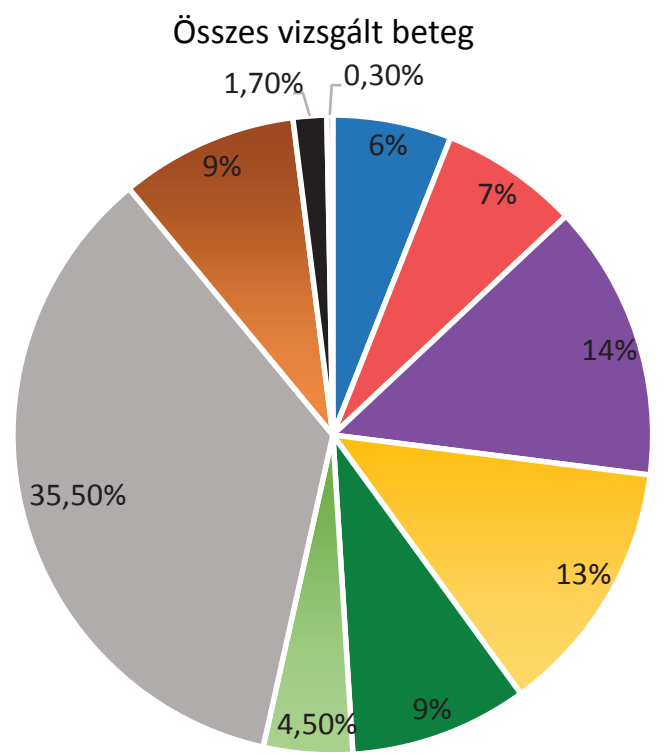

- Amerikai Egyesült Államok = Indiai-óceán térsége

- Karib-térség

- Közép-Amerika

- Ázsia

- Dél-Amerika

- Afrika

- Indonézia

- Csendes-óceán térsége

- Ausztrália

\begin{tabular}{l|l} 
5. ábra & $\begin{array}{l}\text { A leglátogatottabb földrajzi területek megoszlása a vizsgált uta- } \\
\text { zók esetében }\end{array}$
\end{tabular} Igazolt fertőzöttek $0,80 \%$

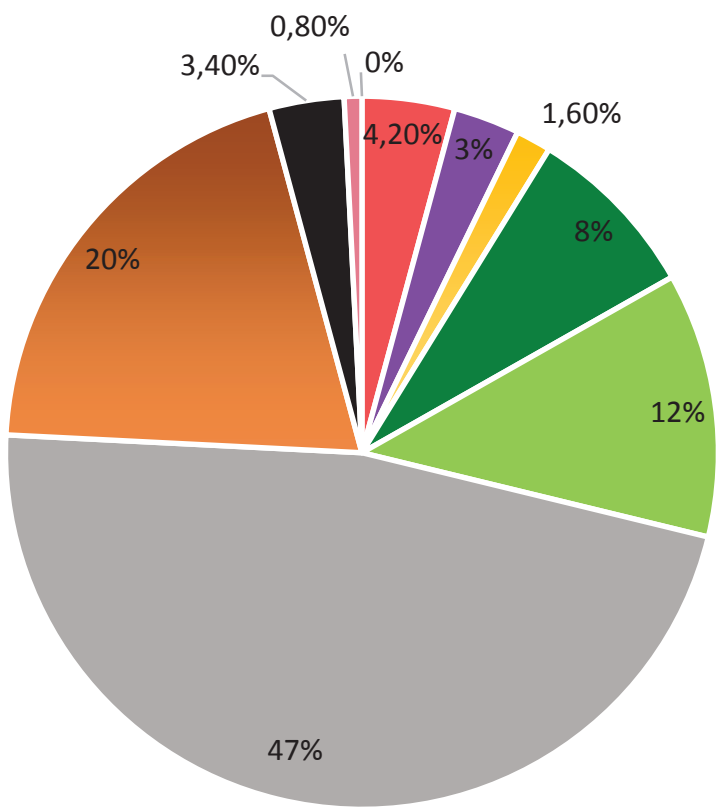

- Amerikai Egyesült Államok

- Indiai-óceán térsége

- Karib-térség

- Ázsia

- Közép-Amerika

- Indonézia

- Dél-Amerika

- Afrika

- Csendes-óceán térsége

- Ausztrália

6. ábra A leglátogatottabb földrajzi területek megoszlása az igazolt betegek esetében 
záltuk. 2018-ban és 2020-ban volt a legalacsonyabb a behurcolt arbovírusfertőzések száma, a 2020-as évben tapasztalt visszaesés döntően a SARS-CoV-2-pandémia következtében lecsökkent utazások számával magyarázható (4. ábra).

A vizsgált betegek és tünetmentes utazók utazási anamnézisét figyelembe véve a leglátogatottabb földrajzi területnek Ázsia, majd Közép- és Dél-Amerika bizonyult. A legtöbb behurcolt fertőzést Ázsiából, majd Indonéziából és az Indiai-óceán térségéből (fơleg a Maldív-szigetekról) diagnosztizáltuk (5., 6. ábra).

A lázon és az általános tüneteken kívül a DENV- és ZIKV-fertőzöttek leggyakoribb tünete a kiütés, míg CHIKV-fertőzésben az ízületi fájdalom volt. Súlyos DENV-fertőzésre jellemző haemorrhagiás tünetek öszszesen három beteg esetében jelentkeztek: a szerológiai válasz alapján mindhárom betegnél második DENVvagy flavivirusfertőzés volt valószínüsíthető, mely az ellenanyagfüggő fertőződésfokozódás jelenségével ma- gyarázhatja a súlyosabb tünetek jelentkezését. DENVfertőzés során az általános bevezető tünetek mellett légúti vagy gastrointestinalis panaszok is kialakultak a betegek egy részénél, illetve jellemző laboreltérés volt a thrombocytopenia és leukopenia is. A DENV-, a CHIKV- és a ZIKV-fertőzés jellemző tüneteinek előfordulását a 7. ábra foglalja össze.

Az igazolt betegek mikrobiológiai vizsgálatai során azt tapasztaltuk, hogy a szakirodalmi adatoknak megfelelően a vírus-RNS kimutatásának esélyét növeli, ha vérsavó mellett alvadásgátolt teljes vér és vizeletminták PCRvizsgálatát is elvégezzük, ezért a tünetes betegek esetében bevezettük ezen mintatípusok vizsgálatát is, és a klinikus kollégák figyelmét felhívtuk a beküldésük fontosságára. Azon betegek esetében, akiknél a fertőzést a nukleinsav-detektálás alapján igazolni tudtuk, az alvadásgátolt teljes vér minták vizsgálata során kaptunk a legnagyobb arányban pozitív eredményt a vizsgált mintatípusok közül mind a DENV, mind a CHIKV- és a ZIKV

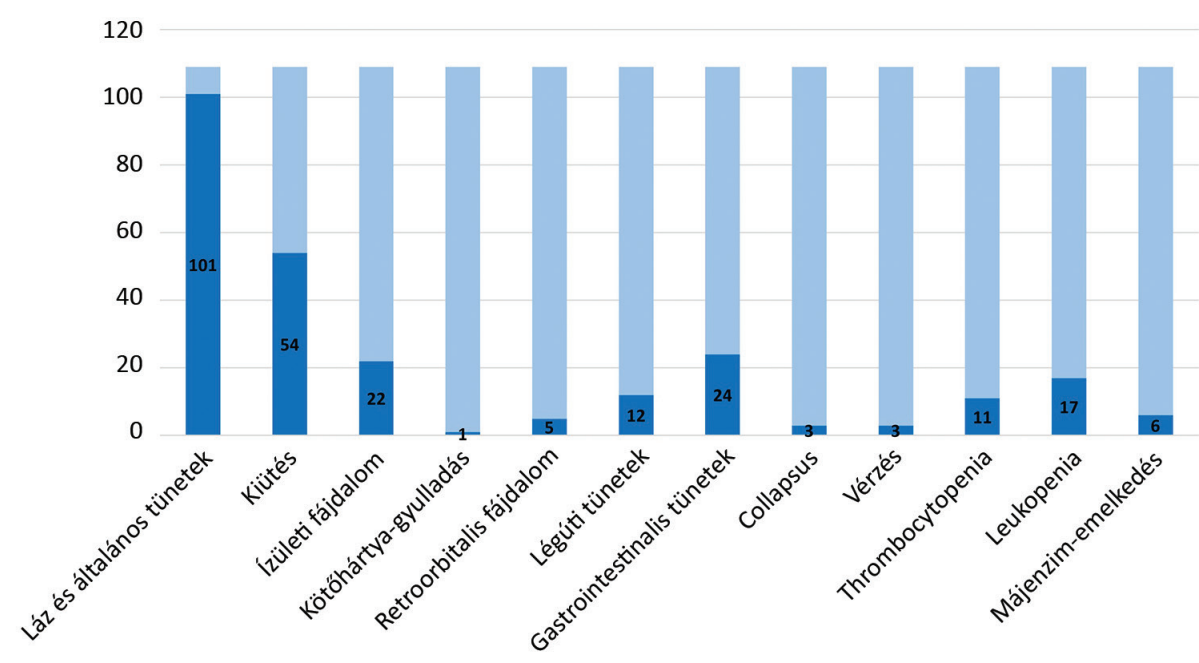

7/a ábra | Az igazolt és valószínűsített behurcolt trópusi arbovírusfertőzések tüneteinek megoszlása a Dengue-vírus-fertőzések esetében

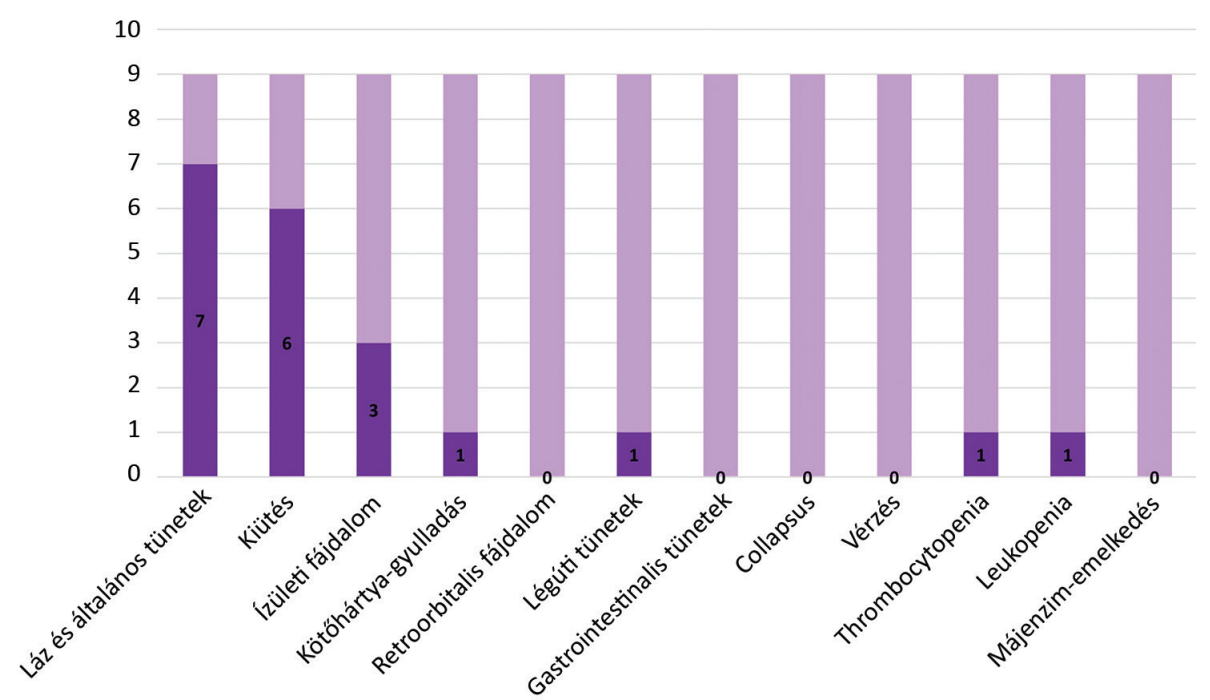

7/b ábra | Az igazolt és valószínúsített behurcolt trópusi arbovírusfertőzések tüneteinek megoszlása a Zika-vírus-fertőzések esetében 


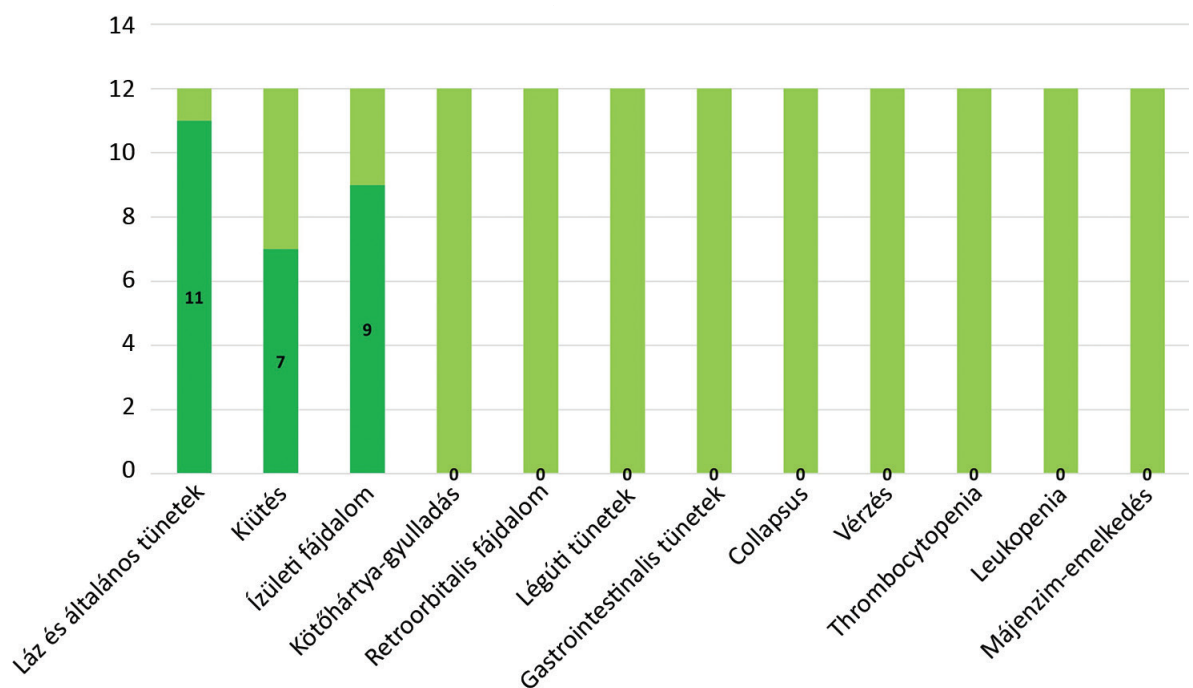

7/c ábra | Az igazolt és valószínúsített behurcolt trópusi arbovírusfertőzések tüneteinek megoszlása a Chikungunya-vírus-fertőzések esetében

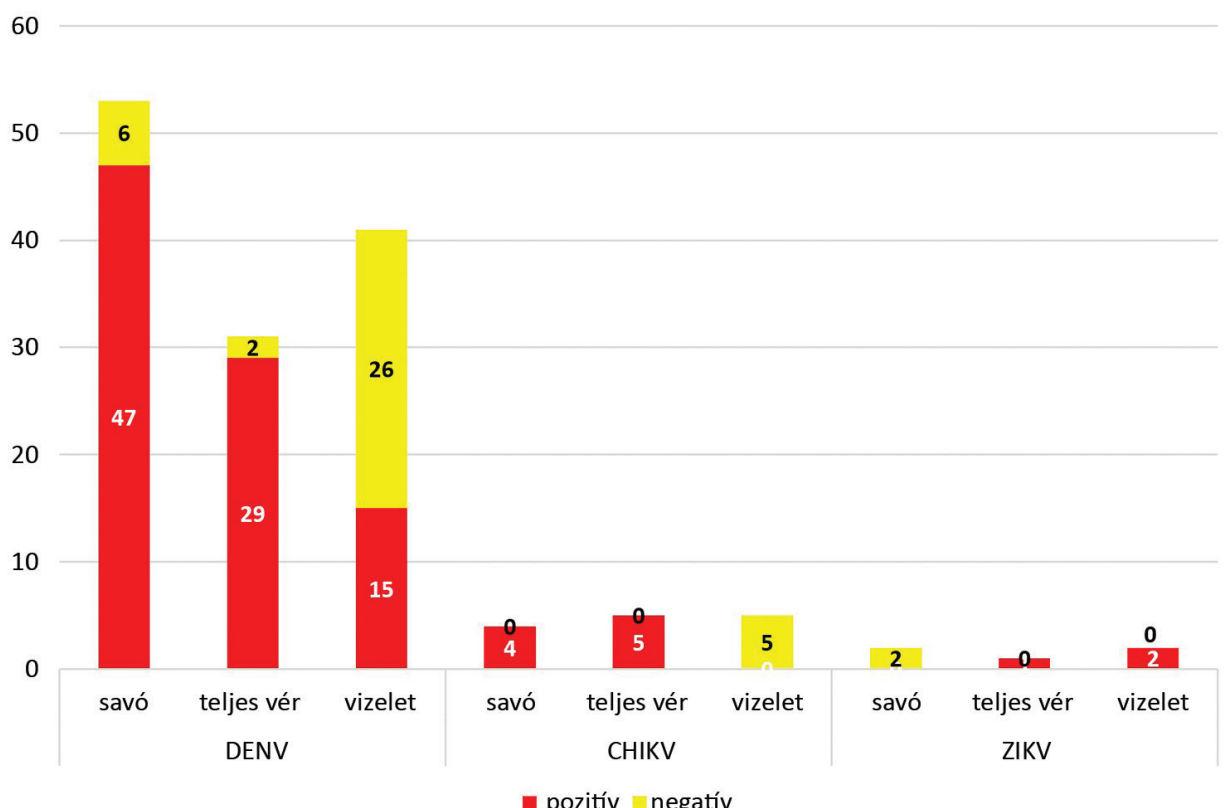

\begin{tabular}{l|l} 
8. ábra & A vírusnukleinsav kimutathatóságának megoszlása különböző mintatípusok esetén pozitív PCR-eredmény alapján igazolt fertőzésekben \\
CHIKV $=$ C
\end{tabular}

esetében. A vizelet a ZIKV-diagnosztikában hasonlóan hasznos mintatípusnak bizonyult, míg a CHIKV esetében a vizsgált vizeletek a PCR-analízis során negatív eredményt adtak (8.ábra).

\section{Megbeszélés}

A 2016 és 2020 között elvégzett vizsgálatok alapján a leggyakrabban importált trópusi arbovírusfertózésnek a DENV bizonyult. A behurcolt DENV-, ZIKV- és CHIKV-fertőzések legjellegzetesebb tünetei a kiütés és az ízületi fájdalom voltak, melyek azonban nem teszik lehetôvé a három vírusfertőzés tünetek alapján történő elkülönítését, ezért a mikrobiológiai vizsgálatokat egy- idejúleg indokolt elvégezni a három vírusfertőzés irányában. Tekintettel a flavi- és alphavirusokra jellemző, rövid ideig tartó viraemiára és a nagyfokú szerológiai keresztreaktivitásra, a molekuláris és a szerológiai vizsgálatok együttes alkalmazása segíti a diagnózis pontos felállítását: ehhez fontos figyelembe venni a betegek oltási és utazási anamnézise alapján felmerülő flavi-, illetve alphavirusok, továbbá a hazánkban endémiás KEV, WNV és USUV szerepét is. A molekuláris vizsgálatok kiterjesztése a vérsavó mellett az alvadásgátolt teljes vér és vizeletmintákra növeli a vírus-RNS kimutathatóságának esélyét, és tünetes betegek esetén ezeket a mintatípusokat is szükséges a laboratóriumba küldeni. Bár a DENV, a ZIKV és a CHIKV elterjedése jelenleg még csak a trópusi és szub- 
trópusi területekre korlátozódik, mivel potenciális vektoraik közül többek között az Aedes albopictus már Európa számos országában jelen van [47], a behurcolt fertőzések mellett az autochton transzmisszió lehetósége is fennáll, és mikrobiológiai vizsgálatuk így kiemelt jelentőségü.

\section{Következtetés}

A vérsavón kívül a vizelet- és alvadásgátolt teljes vér minta PCR-vizsgálata új módszer a flavivirusdiagnosztikában, mely lehetőséget teremt a szerológiai keresztreakciók vagy egy esetleges koinfekció miatt nehezen véleményezhető fertőzések elkülönítésére. Kiemelt jelentőségű a szerepe az immunszupprimáltak fertőzésének diagnosztikájában is, ahol az ellenanyagválasz nem vagy csak csökkent mértékben alakul ki. Továbbá a congenitalis ZIKV-fertőzések igazolása során is kulcsfontosságú vizsgálati módszer, tekintve, hogy a magzati szöveteket és a placentát fertőző vírus elhúzódó anyai vírusürítést okoz [48].

A jövőben tervezzük a DENV-, ZIKV-, CHIKV-vizsgálatok kiterjesztését a nyári hónapokban azon, endémiás területen nem járt betegekre is, akiknél a kórképre jellemző tünetek hátterében más patogén kóroki szerepét nem tudtuk igazolni, hogy az egyre terjedő vektoriális jelenlét következtében kimutathassuk a mediterrán térségből importált vagy az itthon akvirált fertőzéseket is. A vizelet- és vérminta-PCR-vizsgálatok ezen fertőzések differenciáldiagnosztikájában is kiemelt szerepet töltenek majd be, egyrészt a hazai endémiás flavivirusok okozta keresztreakciók kizárására, másrészt a járványügyi nyomon követés és egy esetlegesen hazánkban elterjedő vírusvariáns kimutatására.

Anyagi támogatás: A közlemény megírása, illetve a kapcsolódó kutatómunka intézményen kívüli anyagi támogatásban nem részesült.

Szerzôi munkamegosztás: A kísérletek tervezése, a kísérleti koncepció felállítása: N. O., T. M. A betegek kezelése, mintaküldés, a betegadatok összefoglalása: T. Sz. PCRvizsgálatok beállítása és végzése: N. A., N. O. Szerológiai vizsgálatok végzése: N. O., K. A. A vizsgálatok eredményének értékelése, a kézirat megírása: N. O. A kézirat belső véleményezője: T. M., K. A. A cikk végleges változatát valamennyi szerző elolvasta és jóváhagyta.

Érdekeltségek: A szerzőknek nincsenek érdekeltségeik.

\section{Köszönetnyilvánítás}

Köszönjük Csonka Nikolettnek és Kaposi Tamásnénak a szerológiai vizsgálatok kivitelezése során nyújtott segítséget.

\section{Irodalom}

[1] Weaver SC, Reisen WK. Present and future arboviral threats. Antiviral Res. 2010; 85: 328-345.

[2] Vasilakis N, Weaver SC. Flavivirus transmission focusing on Zika. Curr Opin Virol. 2017; 22: 30-35.

[3] Weaver SC, Barrett AD. Transmission cycles, host range, evolution and emergence of arboviral disease. Nat Rev Microbiol. 2004; 2: 789-801.

[4] Patterson J, Sammon M, Garg M. Dengue, Zika and Chikungunya: emerging arboviruses in the New World. West J Emerg Med. 2016; 17: 671-679.

[5] Centers for Disease Control and Prevention. Division of vectorborne diseases. Memorandum. Revised diagnostic testing for Zika, Chikungunya, and Dengue viruses in US Public Health Laboratories. CDC, Atlanta, GA, February 2016. Available from: https://stacks.cdc.gov/view/cdc/38149 [accessed: February 18,2021$]$.

[6] Mansfield KL, Horton DL, Johnson N, et al. Flavivirus-induced antibody cross-reactivity. J Gen Virol. 2011; 92: 2821-2829.

[7] Henss L, Yue C, Kandler J, et al. Establishment of an alphavirusspecific neutralization assay to distinguish infections with different members of the Semliki Forest complex. Viruses 2019; 11: 82 .

[8] Nagy A, Mezei E, Nagy O, et al. Extraordinary increase in West Nile virus cases and first confirmed human Usutu virus infection in Hungary, 2018. Euro Surveill. 2019; 24: 1900038.

[9] Nagy A, Nagy O, Tarcsai K, et al. First detection of tick-borne encephalitis virus RNA in clinical specimens of acutely ill patients in Hungary. Ticks Tick Borne Dis. 2018; 9: 485-489.

[10] Suhrbier A, Jaffar-Bandjee MC, Gasque P. Arthritogenic alphaviruses - an overview. Nat Rev Rheumatol. 2012; 8; 420-429.

[11] Lanciotti RS, Kosoy OL, Laven JJ, et al. Genetic and serologic properties of Zika virus associated with an epidemic, Yap State, Micronesia, 2007. Emerg Infect Dis. 2008; 14: 1232-1239.

[12] Cao-Lormeau VM, Blake A, Mons S, et al. Guillain-Barré syndrome outbreak associated with Zika virus infection in French Polynesia: a case-control study. Lancet 2016; 387: 1531-1539.

[13] Mlakar J, Korva M, Tul, N, et al. Zika virus associated with microcephaly. N Engl J Med. 2016; 374: 951-958.

[14] World Health Organization. WHO Director-general summarizes the outcome of the Emergency Committee regarding clusters of microcephaly and Guillain-Barré syndrome. WHO, Geneva, February 2016. Available from: https://www.who.int/news/ item/01-02-2016-who-director-general-summarizes-the-outcome-of-the-emergency-committee-regarding-clusters-of-microcephaly-and-guillain-barr\%c3\%a9-syndrome [accessed: February 18,2021$]$.

[15] Giron S, Franke F, Decoppet A, et al. Vector-borne transmission of Zika virus in Europe, Southern France, August 2019. Euro Surveill. 2019; 24: 1900655.

[16] Kim CR, Counotte M, Bernstein K, et al. Investigating the sexual transmission of Zika virus. Lancet Glob Health 2018; 6: e24e25.

[17] Musso D, Gubler DJ. Zika Virus. Clin Microbiol Rev. 2016; 29 : 487-524.

[18] Freitas DA, Souza-Santos R, Carvalho LM, et al. Congenital Zika syndrome: a systematic review. PLoS ONE 2020;15: e0242367.

[19] Varjasi G, Póka R. Zika virus infection in pregnancy. [Zika-vírusfertőzés terhességben.] Orv Hetil. 2017; 158: 563-571. [Hungarian]

[20] European Centre for Disease Prevention and Control. Zika virus transmission worldwide. ECDC, Stockholm, 9 April 2019. Available from: https://www.ecdc.europa.eu/sites/portal/ 
files/documents/zika-risk-assessment-9-april-2019.pdf [accessed: February 18, 2021].

[21] World Health Organization. Dengue and severe Dengue. WHO, Geneva, 2021. Available from: https://www.who.int/newsroom/fact-sheets/detail/dengue-and-severe-dengue [accessed: February 18, 2021].

[22] Wilder-Smith A, Quam M, Sessions O, et al. The 2012 Dengue outbreak in Madeira: exploring the origins. Euro Surveill. 2014; 19: 20718. [Erratum: Euro Surveill. 2014; 19: 20725.]

[23] Narayan R, Tripathi S. Intrinsic AD. The dark side of antibody dependent enhancement during Dengue infection. Front Cell Infect Microbiol. 2020; 10: 580096.

[24] Yacoub S, Wills B. Dengue: an update for clinicians working in non-endemic areas. Clin Med (Lond). 2015; 15: 82-85.

[25] Dissanayake HA, Seneviratne SL. Liver involvement in Dengue viral infections. Rev Med Virol. 2018; 28: e1971.

[26] Thomas SJ, Yoon IK. A review of Dengvaxia ${ }^{\circledR}$ : development to deployment. Hum Vaccin Immunother. 2019; 15: 2295-2314.

[27] Silva JV Jr, Ludwig-Begall LF, Oliveira-Filho EF, et al. A scoping review of Chikungunya virus infection: epidemiology, clinical characteristics, viral co-circulation complications, and control. Acta Trop. 2018; 188: 213-224.

[28] Leparc-Goffart I, Nougairede A, Cassadou S, et al. Chikungunya in the Americas. Lancet 2014; 383: 514.

[29] Amraoui F, Failloux AB. Chikungunya: an unexpected emergence in Europe. Curr Opin Virol. 2016; 21: 146-150.

[30] Delisle E, Rousseau C, Broche B, et al. Chikungunya outbreak in Montpellier, France, September to October 2014. Euro Surveill. 2015; 20: 21108 .

[31] Calba C, Guerbois-Galla M, Franke F, et al. Preliminary report of an autochthonous Chikungunya outbreak in France, July to September 2017. Euro Surveill. 2017; 22: 17-00647.

[32] Vairo F, Mammone A, Lanini S, et al., Chikungunya Lazio Outbreak Group. Local transmission of Chikungunya in Rome and the Lazio region, Italy. PLoS ONE 2018; 13: e0208896.

[33] Venturi G, Di Luca M, Fortuna C, et al. Detection of a Chikungunya outbreak in Central Italy, August to September 2017. Euro Surveill. 2017; 22: 17-00646.

[34] Javelle E, Ribera A, Degasne I, et al. Specific management of post-Chikungunya rheumatic disorders: a retrospective study of 159 cases in Reunion Island from 2006-2012. PLoS Negl Trop Dis. 2015; 9: e0003603.

[35] Cerny T, Schwarz M, Schwarz U, et al. The range of neurological complications in Chikungunya fever. Neurocrit Care 2017; 27: $447-457$.

[36] Van den Bossche D, Cnops L, Van Esbroeck M. Recovery of Dengue virus from urine samples by real-time RT-PCR. Eur J Clin Microbiol Infect Dis. 2015; 34: 1361-1367.

[37] Alagarasu K, Kakade MB, Bachal RV, et al. Use of whole blood over plasma enhances the detection of Dengue virus RNA: pos- sible utility in Dengue vaccine trials. Arch Virol. 2021; 166: $587-591$

[38] Bingham AM, Cone M, Mock V, et al. Comparison of test results for Zika virus RNA in urine, serum, and saliva specimens from persons with travel-associated Zika virus disease - Florida, 2016. MMWR Morb Mortal Wkly Rep. 2016; 65: 475-478.

[39] Voermans JJ, Pas SD, van der Linden A, et al. Whole-blood testing for diagnosis of acute Zika virus infections in routine diagnostic setting. Emerg Infect Dis. 2019; 25: 1394-1396.

[40] Mansuy JM, Lhomme S, Cazabat M, et al. Detection of Zika, Dengue and Chikungunya viruses using single-reaction multiplex real-time RT-PCR. Diagn Microbiol Infect Dis. 2018; 92: 284-287.

[41] Comission implementing decision (EU) 2018/945 of 22 June 2018 on the communicable diseases and related special health issues to be covered by epidemiological surveillance as well as relevant case definitions. Official J EU 2018; 6.7: L 170. Available from: https://eur-lex.europa.eu/legal-content/EN/TXT/ PDF/?uri=CELEX:32018D0945 [accessed: February 18, 2021].

[42] Kassim FM, Izati MN, TgRogayah TA, et al. Use of Dengue NSI antigen for early diagnosis of Dengue virus infection. Southeast Asian J Trop Med Public Health 2011; 42: 562-569.

[43] Muller DA, Depelsenaire AC, Young PR. Clinical and laboratory diagnosis of Dengue virus infection. J Infect Dis. 2017; 215(Suppl 2): S89-S95.

[44] Caglioti C, Lalle E, Castilletti C, et al. Chikungunya virus infection: an overview. New Microbiol. 2013; 36: 211-227.

[45] European Centre for Disease Prevention and Control. Interim guidance for healthcare providers and Zika virus laboratory diagnosis. ECDC, Stockholm, 1 Apr 2016. Available from: https:// www.ecdc.europa.eu/en/publications-data/interim-guidancehealthcare-providers-and-zika-virus-laboratory-diagnosis [accessed: February 18, 2021].

[46] Nagy O, Nagy A, Tóth S, et al. Imported Zika virus infections in Hungary between 2016 and 2018. Acta Microbiol Immunol Hung. 2019; 66: 423-442.

[47] European Centre for Disease Prevention and Control. Aedes albopictus - current known distribution. ECDC, Stockholm, May 2020. Available from: https://www.ecdc.europa.eu/en/ publications-data/aedes-albopictus-current-known-distribution-may-2020 [accessed: February 18, 2021].

[48] Driggers RW, Ho CY, Korhonen EM, et al. Zika virus infection with prolonged maternal viremia and fetal brain abnormalities. N Engl J Med. 2016; 374: 2142-2151.

(Takács Mária dr., Budapest, Albert Flórián út 2-6., 1097 e-mail: takacs.maria@nnk.gov.hu)

A cikk a Creative Commons Attribution 4.0 International License (https://creativecommons.org/licenses/by/4.0/) feltételei szerint publikált Open Access közlemény, melynek szellemében a cikk bármilyen médiumban szabadon felhasználható, megosztható és újraközölhetö, feltéve, hogy az eredeti szerzỏ és a közlés helye, illetve a CC License linkje és az esetlegesen végrehajtott módosítások feltüntetésre kerülnek. (SID_1) 